\title{
Effects of smoking on healthy young men's hematologic parameters
}

\author{
Besime Inal ${ }^{1}$, Tuba Hacıbekiroglu², Bilger Cavus ${ }^{3}$, Zeliha Musaoglu ${ }^{1}$, \\ Hatice Demir ${ }^{4}$, Berrin Karadag 5 \\ ${ }^{1}$ Department of Family Medicine, Pinarhisar State Hospital, Kirklareli, Turkey; \\ 2Department of Hematology, Edirne State Hospital, Edirne, Turkey; \\ ${ }^{3}$ Department of Internal Medicine, Pinarhisar State Hospital, Kırklareli, Turkey; \\ ${ }^{4}$ Department of Biochemistry, Kirklareli State Hospital, Kirklareli; Turkey; \\ ${ }^{5}$ Department of Geriatrics, Acibadem University Faculty of Medicine, Istanbul, Turkey
}

\section{ABSTRACT}

OBJECTIVE: Cigarette smoking carries higher risks for most of the chronic diseases. It also has chronic and acute effects on the hematologic system. This study explores the effects of cigarette smoking on some blood values of the healthy young male smokers.

METHODS: In this study, cigarette smoking and usage of substance, additional diseases, birth places, and education levels of 171 healthy male subjects between the ages of 20 and 30 years were investigated. Anthropometric measurements of the cases were obtained. Thyroid function tests, vitamin B12, folic acid, ferritin, ferrous/Iron, total Iron binding capacity, leucocytes, platelets, hemoglobin, hematocrit, mean corpuscular volume (MCV), mean platelet volume (MPV), HBs AG, Anti-HBs and Anti-HIV were evaluated. Groups of smokers and nonsmokers were compared. The group of smokers was also sorted into subgroups of " 2 year-smokers", " 5 year-smokers" and "10 year-smokers" according to their pack-years of smoking. The effects of pack-years of smoking on the blood values were also investigated.

RESULTS: The MCV values of the group of smokers were higher than the values of nonsmokers, which were statistically significant $(p<0.05)$. As a result of the subgroup analyses of smokers, the white blood cell (WBC) counts of the individuals smoking for 5 or more years were significantly higher than those with a history of smoking less than 5 years, $(p<0.05)$.

CONCLUSION: This study supports the idea that cigarette smoking and especially longer durations of smoking have adverse effects on the hematologic parameters.

Key words: Cigarette, hematologic parameters, young man

Received: August 06, 2014 Accepted: August 12, 2014 Online: August 03, 2014

Correspondence: Besime INAL. Ankara Sami Ulus Cocuk Hastanesi, Balgat Semt Poliklinigi, Ankara, Turkey.

Tel: +90 312 - 3170707 e-mail: besimeinal@gmail.com

(c) Copyright 2014 by Istanbul Northern Anatolian Association of Public Hospitals - Available online at www.kuzeyklinikleri.com 
Cmoking is the most important public health $\checkmark$ problem. Many studies performed have proved its deleterious effects on many organ systems mainly respiratory,and cardiovascular systems. With 6000 chemical substance it contains, it exerts pharmacological, mutagenic, cancerogenic, toxic, and inflammatory effects [1]. Nowadays, it is responsible for every six cases of death [2]. Cigarette contains carcinogens (polycyclic aromatic hydrocarbons etc.), irritant substances, nicotine, carbon monoxide, and other gases. Cigarette smoke contains many oxidants, and free radicals which can harm lipids, proteins, DNA, carbohydrates, and other biomolecules [3]. The effects of smoking on various metabolic, and biological processes, hormone secretion, and hematopoietic system have been demonstrated. In many studies, among acute effects of smoking on hematological system, increases in WBC, eosinophil, and platelet (PLT) counts have been shown [1]. A correlation was established between smoking, and WBC counts. Relatively higher WBC counts were detected in smokers $[4,5,6,7,8,9,10]$. Smoking has been suggested to increase the levels of hematological parameters as hemoglobin $(\mathrm{Hb})$ concentration, red blood cell (RBC), neutrophil, eosinophil, monocyte, and platelet counts. Smoking cessation studies have demonstrated that some of these changes are reversible, and transitory in case of cessation of smoking [11]. In our study, we investigated the effects of smoking, and especially duration of smoking in healthy young men on anthropometric measurements, thyroid function tests, vitamin B12, folic acid, ferritin, serum iron, total iron binding capacity (TIBC), whole blood counts, $\mathrm{HBsAg}$, anti$\mathrm{HBs}$, anti-HCV, and anti-HIV values.

\section{MATERIALS AND METHODS}

Our cross-sectional study was performed on healthy 171 male patients aged 20-30 years who consulted to Pinarhisar State Hospital between October 2012, and February 2013 for any indication. The first group consisted of smokers, and the second group of life-time nonsmokers. The cases who had acute infections, chronic diseases, acute bleeding episodes, cancer patients, and corticosteroid drug users were not included in the study. From available recordings, patient's age, measurements of body weight $(\mathrm{kg})$, height $(\mathrm{cm})$, waist circumference $(\mathrm{cm})$, and blood pressures were retrieved. Measurements of body weight, and height were made while barefooted patients were wearing light clothes. Body mass index (BMI) was calculated by dividing body weight $(\mathrm{kg})$ by square meter of the height. Waist circumference was measured from the midpoint between the costal arch, and spina iliaca anterior superior. Arterial blood pressure (ABP) was measured using mercury sphygomanometer. The cuff of the sphygomanometer was wrapped around the arm with its lower end $2.5-3 \mathrm{~cm}$ away from the cubital fossa. Cuff was placed on the brachial artery. Information about educational level, smoking status, substance use, and existing disease was recorded after verbal approval of the patient.

Thyroid function tests (thyroid stimulating hormone: TSH, free T4: fT4, free T3: fT3), vitamin B12, ferritin, and folic acid were analyzed with electrochemiluminescence method using Roche cobas e 601 device. Normal ranges of some analytes set for this device were: TSH, 0.27-4.20 uIU/mL; fT4, 12-22 pmol/L; fT3, 3.1-6.8) pmol/L, vitamin B1, 156-698 $\mathrm{pmol} / \mathrm{L}$; ferritin $30-400 \mathrm{ng} / \mathrm{mL}$, and folic acid, $4.6-34.8 \mathrm{ng} / \mathrm{mL}$.

Hepatitis B surface antigen ( $\mathrm{HBsAg}$ ), antibodies both to the surface antigen (anti-HBs), HCV (antiHCV), Anti -HIV tests were analyzed in Roche cobas e 411 device using an electrochemiluminescence method. Normal ranges of some analytes set for this device were: $\mathrm{HbsAg}, 0-1 \mathrm{~S} / \mathrm{CO}$, Anti Hbs negativity, 0-9.999 IU/L, Anti Hbs positivity, $\geq 10 \mathrm{IU} / \mathrm{L}$; Anti HCV 0-1 S/CO; Anti -HIV, 0-1 S/CO.

Iron, and iron binding capacity were tested in Roche cobas c 501 device using a colorimetric method. Normal ranges for iron, and iron binding capacity were accepted as 33-193 ug/dl, and 250$450 \mathrm{ug} / \mathrm{dl}$, respectively.

Hemoglobin, hematocrit, white blood cell, and platelet counts, mean erythrocyte, and platelet volumes were assessed in ABX Pentra DF device using electronic cell counter method. Normal ranges of some analytes accepted for this device were: he- 
moglobin 11-16.5 g/dL, hematocrit 34-48\%, WBC 3.8-9.8 103/uL; platelets, 180-350 103/uL; MCV, 80-100 fL, and MPV 7.6-10.8 fL.

\section{Statistical analysis}

For descriptive analysis of data mean, standard deviation, ratio, and frequencies were used. Distribution of variables was controlled with KolmogorovSmirnov test. In the analysis of quantitative data Mann-Whitney-U test, and independent sampling test, and for qualitative data chi-square test, and if not suitable Fisher's exact test were used. In statistical analyses, SPSS 21.0 program was used.

\section{RESULTS}

A total of 171 healthy male individuals aged 20-30 years were included in the study, and divided into smoker $(\mathrm{n}=101)$, and nonsmoker $(\mathrm{n}=70)$ groups.

Between smoker, and nonsmoker youngsters, a significant difference was not found as for age, body weight, waist circumference, ABP, and co-

TABLE 1. Anthropometric measurements, educational level, blood pressure values, substance use, hepatitis markers, and presence of comorbities groups of smokers, and nonsmokers

\begin{tabular}{|c|c|c|c|c|c|c|c|}
\hline & \multicolumn{3}{|c|}{ Smokers } & \multicolumn{3}{|c|}{ Nonsmokers } & \multirow[t]{2}{*}{$\mathrm{p}$} \\
\hline & $\mathrm{n}$ & $\%$ & Mean \pm SD & $\mathrm{n}$ & $\%$ & Mean \pm SD & \\
\hline Age (years) & & & $21.96 \pm 2.34$ & & & $21.55 \pm 2.20$ & 0.182 \\
\hline BMI $\left(\mathrm{kg} / \mathrm{m}^{2}\right)$ & & & $23.91 \pm 3.35$ & & & $22.67 \pm 3.57$ & 0.022 \\
\hline Waist circumference (cm) & & & $85.44 \pm 7.81$ & & & $84.43 \pm 7.99$ & 0.412 \\
\hline \multicolumn{8}{|l|}{ Educational level } \\
\hline None & 1 & 1.4 & & 3 & 3.0 & & 0.033 \\
\hline Primary & 13 & 18.3 & & 11 & 11.0 & & \\
\hline Secondary & 20 & 28.2 & & 51 & 51.0 & & \\
\hline Lycée & 18 & 25.3 & & 22 & 22.0 & & \\
\hline University & 19 & 26.8 & & 13 & 13.0 & & \\
\hline \multicolumn{8}{|l|}{ Hypertension (ABP) mmHg } \\
\hline Yes & 68 & 95.8 & & 95 & 95.0 & & 0.813 \\
\hline No & 3 & 4.2 & & 5 & 5.0 & & \\
\hline \multicolumn{8}{|l|}{ Substance use } \\
\hline Yes & 70 & 98.6 & & 89 & 89.0 & & 0.016 \\
\hline No & 1 & 1.4 & & 11 & 11.0 & & \\
\hline \multicolumn{8}{|l|}{ Comorbidity } \\
\hline Yes & 67 & 94.4 & & 91 & 91.0 & & 0.413 \\
\hline No & 4 & 5.6 & & 9 & 9.0 & & \\
\hline \multicolumn{8}{|l|}{ HBsAg (S/CO) } \\
\hline None & 71 & 100 & & 96 & 96.0 & & 0.088 \\
\hline Present & 0 & 0 & & 4 & 4.0 & & \\
\hline \multicolumn{8}{|l|}{ AntiHBs (S/CO) } \\
\hline None & 43 & 60.6 & & 51 & 51.0 & & 0.215 \\
\hline Present & 28 & 39.4 & & 49 & 49.0 & & \\
\hline
\end{tabular}

BMI: Body Mass İndex; Chi-square test/Independent samples t-test/Mann-Whitney U test. 
morbidities ( $p>0.05)$, (Table 1). BMIs, and educational level (lycée or university) were significantly lower in smokers when compared with nonsmokers $(p<0.05)$. Still substance use among smokers, was significantly higher when compared with nonsmokers. $(p<0.05)$, (Table 1$)$. Smoking had not any significant effect on HBsAg, antiHBs, TSH, fT4, fT3, vitamin B12, folic acid, PLT, Hb, Htc, MPV, ferritin, iron, and TIBC values, however MCV values of young smokers were observedly higher than those of the nonsmokers $(\mathrm{p}<0.05)$, (Table 2).

When group of smokers was classified based on duration of smoking of $<2$ (Group 1 ), and $\geq 2$ (Group 2) years, age, height, body weight, waist circumference, BMI, educational level, substance use, $\mathrm{ABP}$ values, incidence of comorbidities, $\mathrm{HBsAg}$, antiHBs, TSH, fT4, fT3, vitB12, folic acid, WBC, PLT, Hb, Htc, MCV, MPV, ferritin, iron, TBIC values did not differ between groups $(\mathrm{p}>0.05)$.

Age, height, body weight, waist circumference, BMI, educational level, substance use, ABP values, incidence of comorbidities, $\mathrm{HBsAg}$, antiHBs, TSH, fT4, fT3, vitB12, folic acid, WBC, PLT, Hb,
Htc, MCV, MPV, ferritin,iron, TBIC values did not differ according to the years of smoking for less or more than 5 years, respectively $(p>0.05)$. While WBC values were found to be significantly higher in young male individuals with a smoking history of $\geq 5$ years $(p<0.05)$, (Table 3$)$.

Any significant difference was not detected as for height, body weight, waist circumference, educational level, substance use, comorbidities, and $\mathrm{ABP}$ values between groups of individuals with a smoking history of $<10$, and $>10$ years, respectively $(\mathrm{p}>0.05)$. While WBC values were found to be significantly higher in young male individuals with a smoking history of more than 10 years $(\mathrm{p}<0.05)$.

\section{DISCUSSION}

Smoking is known as a high risk factor for cardiovascular diseases, hypertension, inflammation, stroke, coagulopathies, and respiratory diseases [4, $5,6,7,8,9,10]$. Besides, as shown in various studies, smoking accelerates cancerogenesis in various organs as lungs, pancreas, kidney, and liver [5, 6,

TABLE2. Whole blood cell counts, and hormonal values of the groups

\begin{tabular}{|c|c|c|c|c|}
\hline & Nonsmokers & Smokers & $\mathrm{p}$ & \\
\hline & Mean \pm SD & Mean \pm SD & & \\
\hline TSH (uIU/mL) & $1.86 \pm 0.81$ & $1.74 \pm 0.83$ & 0.340 & \\
\hline Ft4 (pmol/L) & $15.46 \pm 1.97$ & $15.55 \pm 1.70$ & 0.740 & \\
\hline Ft3 (pmol/L) & $5.77 \pm 0.67$ & $5.77 \pm 0.66$ & 0.971 & \\
\hline VitB12 (pmol/L) & $206.80 \pm 81.57$ & $216.09 \pm 81.25$ & 0.463 & \\
\hline Folic acid $(\mathrm{ng} / \mathrm{mL})$ & $6.93 \pm 1.69$ & $6.65 \pm 1.83$ & 0.298 & \\
\hline WBC (uL) & $7.23 \pm 1.94$ & $7.36 \pm 1.85$ & 0.675 & \\
\hline PLT (uL) & $250.41 \pm 59.12$ & $246.62 \pm 70.17$ & 0.323 & $\mathrm{~m}$ \\
\hline $\mathrm{Hb}(\mathrm{g} / \mathrm{dL})$ & $14.98 \pm 1.09$ & $15.11 \pm 1.42$ & 0.520 & \\
\hline $\mathrm{Htc}(\%)$ & $44.97 \pm 3.63$ & $44.76 \pm 5.45$ & 0.874 & $\mathrm{~m}$ \\
\hline MCV (fL) & $84.34 \pm 3.68$ & $85.59 \pm 3.94$ & 0.035 & \\
\hline $\mathrm{MPV}(\mathrm{fL})$ & $7.58 \pm 0.89$ & $7.66 \pm 1.28$ & 0.671 & \\
\hline Ferritin $(\mathrm{ng} / \mathrm{mL})$ & $88.72 \pm 67.41$ & $82.06 \pm 65.64$ & 0.498 & $\mathrm{~m}$ \\
\hline Iron (ug/dl) & $86.56 \pm 34.02$ & $89.20 \pm 35.21$ & 0.623 & \\
\hline TIBC (ug/dl) & $334.61 \pm 54.76$ & $330.91 \pm 57.19$ & 0.670 & \\
\hline
\end{tabular}

Independent samples t-test / Mann-Whitney $\mathrm{U}$ test. 
TABLE 3. Correlations between cigarette smoking for less or more than 5 years, and some hematological parameters

\begin{tabular}{|c|c|c|c|}
\hline & Smoking history $\leq 5$ years & Smoking history $<5$ years & $\mathrm{p}$ \\
\hline & Mean \pm SD & Mean \pm SD & \\
\hline TSH (uIU/mL) & $1.65 \pm 0.87$ & $1.85 \pm 0.77$ & 0.230 \\
\hline Ft4 (pmol/L) & $15.77 \pm 1.84$ & $15.28 \pm 1.49$ & 0.158 \\
\hline Ft3 (pmol/L) & $5.71 \pm 0.67$ & $5.83 \pm 0.64$ & 0.374 \\
\hline vitB12 (pmol/L) & $207.55 \pm 81.30$ & $226.96 \pm 80.79$ & 0.238 \\
\hline Folic acid $(\mathrm{ng} / \mathrm{mL})$ & $6.35 \pm 1.49$ & $7.03 \pm 2.14$ & 0.063 \\
\hline WBC (uL) & $6.98 \pm 1.55$ & $7.83 \pm 2.10$ & 0.022 \\
\hline PLT (uL) & $249.38 \pm 75.08$ & $243.11 \pm 64.05$ & 0.779 \\
\hline $\mathrm{Hb}(\mathrm{g} / \mathrm{dL})$ & $15.18 \pm 1.42$ & $15.01 \pm 1.43$ & 0.564 \\
\hline Htc $(\%)$ & $45.19 \pm 3.57$ & $44.21 \pm 7.18$ & 0.236 \\
\hline $\operatorname{MCV}(f L)$ & $85.61 \pm 4.21$ & $85.57 \pm 3.61$ & 0.961 \\
\hline MPV (fL) & $7.61 \pm 0.81$ & $7.72 \pm 1.70$ & 0.674 \\
\hline Ferritin $(\mathrm{ng} / \mathrm{mL})$ & $78.14 \pm 76.69$ & $87.05 \pm 48.51$ & 0.085 \\
\hline Iron (ug/dl) & $85.79 \pm 40.33$ & $93.55 \pm 27.19$ & 0.276 \\
\hline TBIC (ug/dl) & $332.14 \pm 53.82$ & $329.34 \pm 61.81$ & 0.809 \\
\hline
\end{tabular}

Independent samples t-test/Mann-Whitney-U test.

12]. Effects of smoking on hemapoietic system have been also analyzed in many studies. In our study, we also investigated the impact of smoking on hematological parameters.

The mechanism of action of smoking on WBC is not clear-cut yet. In smokers, lymphocytosis is thought to be mainly associated with an increase in T-cells [13]. Nicotine which is a component of cigarette smoke, stimulates cathecolamine release, and induces increase in cortisol levels. Increases in peripheral blood WBC counts, and alterations in WBC function can be the result of direct damage stemming from alterations in epithelial, and endothelial surfaces and/or cytokine levels (especially IL-6) caused by components of cigarette smoke [14]. In a study on the impact of smoking on hematological parameters, WBC, red blood cells, $\mathrm{Hb}$, and Htc levels were found to be markedly increased, while MCV, and platelet counts were lower. These changes have been associated with atherosclerosis, polycythemia vera, chronic obstructive pulmonary disease, and cardiovascular diseases, and also higher risk of atherosclerosis, polycythemia, chronic ob- structive pulmonary disease, and cardiovascular disease in smokers has been revealed [15]. Kurtoğlu et al. detected that smoking significantly increased WBC, neutrophil, lymphocyte, monocyte, platelet counts, Hb, Hct, and RBC indexes in both genders [16]. Also some studies comparing smoker, and nonsmoker groups have demonstrated increases in $\mathrm{Hb}, \mathrm{Hct}, \mathrm{RBC}, \mathrm{MCV}, \mathrm{WBC}$, neutrophil, lymphocyte, eosinophil, and monocyte counts in both groups $[17,18,19,20,21,22]$. Similarly when smokers, and nonsmokers were compared, rates of $\mathrm{MCV}$ were found to be significantly higher in smokers in compliance with the literature. Zafar et al. investigated the impact of smoking on $\mathrm{RBC}$, $\mathrm{WBC}$, and $\mathrm{Hb}$, and indicated increases in WBC counts, and decreases in $\mathrm{RBC}$, and WBC counts in smokers. Linear regression model demonstrated a positive correlation between number of pack-years, and total WBC count, and the authors stressed the importance of these increments. Presence of a positive correlation has been revealed between pack-years of smoking, and WBC counts. Studies displayed sustained, and important increments in 
WBC counts in line with pack-years of smoking. Even smoking 10 cigarettes a day led to important increase in WBC counts [23].

In our study, when we analyzed the impact of years of smoking on WBC counts, we detected significant increases in WBC counts in individuals with a smoking history of 5 or more years. However in individuals who used tobacco products for less than 5 years, we couldn't detect any effect of smoking on WBC counts. Our study population consisted of healthy young adults without any chronic disease. We think that effects of smoking in individuals without any history of chronic disease can be seen at an earlier phase.

The harmful effects of smoking on hematological parametres improve with a little bit decrease in the daily number of cigarettes smoked. If chronic smokers quit smoking, then, as has been demonstrated in many studies, most of the parameters related to red, and white blood cells rapidly return to their normal values [24].

Even though place of smoking in social life has changed in recent years, it is prevalent among people of lower socioeconomic status as had been previously. Smoking age has decreased down to pediatric age owing to social pressure, and popular culture [25]. Our study population consisted of youngsters aged 20-30 years. Our cases with a median age of 21 , comprised most of our study population who had been using tobacco products for 5 years. Some of our patients started to use cigarettes while they were just a small child, and continued to use them for 15 years. Substance use was more frequent among smokers. Educational level of smokers (lycée, and high school) was significantly lower relative to nonsmokers which reveals the importance of education. Awareness should be raised in the community about smoking, and its harmful effects. With decrease in the prevalence of smoking, the incidence of chronic diseases whose treatment incur a great financial burden on public expenditures will drop significantly.

In conclusion, in our study, unfavourable effects of smoking on hematological parameters have been demonstrated, and correlation between pack-years, and these harmful effects have been determined.
Physicians who have an important role in the protection of public health, should inquire from their patients about their smoking history at every visit, and recommend cessation of smoking. Even though public awareness about harmful effects of smoking has been raised considerably, still every effort should be made on this issue.

Conflict of Interest: No conflict of interest was declared by the authors.

Financial Disclosure: The authors declared that this study has received no financial support.

\section{REFERENCES}

1. Öztuna F. Sigaranın hücresel etkileri. Akkciğer Arşivi 2004;2:111-6.

2. Kumar Cotran Robbins. Basic pathology. Çevikbaş U. 6. Baskı, Elma Basım; 2000.

3. Al-Azzawy LHA, Al-Qaicy AGS. A study about some physiological parameters in smokers. Ibn Al-Haitham $\mathrm{J}$ for Pure \& Appl 2011;24. Available at http://www.iasj.net/ iasj?func $=$ fulltext $\& a I d=5108$.

4. Abel GA, Hays JT, Decker PA, Croghan GA, Kuter DJ, Rigotti NA. Effects of biochemically confirmed smoking cessation on white blood cell count. Mayo Clin Proc 2005;80:1022-8. CrossRef

5. Yarnell JW, Baker IA, Sweetnam PM, Bainton D, O'Brien JR, Whitehead PJ, et al. Fibrinogen, viscosity, and white blood cell count are major risk factors for ischemic heart disease. The Caerphilly and Speedwell collaborative heart disease studies. Circulation 1991;83:836-44. CrossRef

6. Carel RS, Eviatar J. Factors affecting leukocyte count in healthy adults. Prev Med 1985;14:607-19. CrossRef

7. de Heens GL, Kikkert R, Aarden LA, van der Velden U, Loos BG. Effects of smoking on the ex vivo cytokine production in periodontitis. J Periodontal Res 2009;44:28-34. CrossRef

8. Wannamethee SG, Lowe GD, Shaper AG, Rumley A, Lennon L, Whincup PH. Associations between cigarette smoking, pipe/ cigar smoking, and smoking cessation, and haemostatic and inflammatory markers for cardiovascular disease. Eur Heart J 2005;26:1765-73. CrossRef

9. Freedman DS, Flanders WD, Barboriak JJ, Malarcher AM, Gates L. Cigarette smoking and leukocyte subpopulations in men. Ann Epidemiol 1996;6:299-306. CrossRef

10. Van Tiel E, Peeters PH, Smit HA, Nagelkerke NJ, Van Loon AJ, Grobbee DE, et al. Quitting smoking may restore hematological characteristics within five years. Ann Epidemiol 2002;12:37888. CrossRef

11. McKarns SC. Smoker-nonsmoker comparative study. 1992:3070.

12. Islam MM Amin MR, Begum S, Akther D, Rahman A. Total 
count of white blood cells in adult male smokers. J Bangladesh Soc Physiol 2007;2:49-53.

13. Silverman NA, Potvin C, Alexander JC Jr, Chretien PB. In vitro lymphocyte reactivity and T-cell levels in chronic cigarette smokers. Clin Exp Immunol 1975;22:285-92.

14. Smith MR, Kinmonth AL, Luben RN, Bingham S, Day NE, Wareham NJ, et al. Smoking status and differential white cell count in men and women in the EPIC-Norfolk population. Atherosclerosis 2003;169:331-7. CrossRef

15. Asif M, Karim S, Umar Z, Malik A, Ismail T, Chaudhary A. Effect of cigarette smoking based on hematological parameters: comparison between male smokers and nonsmokers. Turkish Journal of Biochemistry-Turk J Biochem 2013;38:75-80. CrossRef

16. Kurtuğlu E, Uğur A. Sigara kullanımının kan sayımı parametreleri üzerine etkileri. XXXIII. Ulusal Hematoloji Kongresi özet kitabı, Ankara: 2007:34.

17. Corre F, Lellouch J, Schwartz D. Smoking and leucocyte-counts. Results of an epidemiological survey. Lancet 1971;2:632-4. CrossRef

18. Helman N, Rubenstein LS. The effects of age, sex, and smoking on erythrocytes and leukocytes. Am J Clin Pathol 1975;63:3544.

19. Dodsworth H, Dean A, Broom G. Effects of smoking and the pill on the blood count. Br J Haematol 1981;49:484-8. CrossRef
20. Tollerud DJ, Clark JW, Brown LM, Neuland CY, Mann DL, Pankiw-Trost LK, et al. The effects of cigarette smoking on T cell subsets. A population-based survey of healthy caucasians. Am Rev Respir Dis 1989;139:1446-51. CrossRef

21. Yarnell JW, Sweetnam PM, Rogers S, Elwood PC, Bainton D, Baker IA, et al. Some long term effects of smoking on the haemostatic system: a report from the Caerphilly and Speedwell Collaborative Surveys. J Clin Pathol 1987;40:909-13. CrossRef

22. Whitehead TP, Robinson D, Allaway SL, Hale AC. The effects of cigarette smoking and alcohol consumption on blood haemoglobin, erythrocytes and leucocytes: a dose related study on male subjects. Clin Lab Haematol 1995;17:131-8.

23. Zafar I, Mohammad KN, Nisar M, Rashida M, Shumaila B.. Effect of cigarette smoking on erythrocytes, leukocytes and haemoglobin. Journal of Medical Sciences 2003;3:245-50. CrossRef

24. Bain BJ, Rothwell M, Feher MD, Robinson R, Brown J, Sever PS. Acute changes in haematological parameters on cessation of smoking. J R Soc Med 1992;85:80-2.

25. Önen ZP, Şen E, Eriş Gülbay B, Öztürk A, Akkoca Yıldız Ö, Acıcan $\mathrm{T}$ ve ark. Farklı tedavi yöntemlerinin sigara bırakma başarısı üzerine etkilerini değerlendirmek. Türk Toraks Derneği 11. Y1llık Kongresi, 23-27 Nisan 2008, Antalya: 2008. p. 337. 